\title{
Contabilidad social.
}

\section{Análisis de un académico de número}

Social Accounting - Analysis of a Full Member

Contabilidade social - Análise de um número académico

Hugo Ricardo Arreghini

Universidad del Centro de la Provincia

de Buenos Aires, Universidad

de Buenos Aires, Argentina.

E-mail: harreghini@gmail.com

Fecha de recepción: 21/07/2020

Fecha de aceptación: 09/11/2020

\section{Resumen}

El análisis de la argumentación empleada y de los procedimientos aplicables, presentados como testimonios escritos para comunicar los efectos sociales provocados por las entidades económicas, que son la opinión documentada del catedrático al que se atribuye ser promotor de esas prácticas en América Latina, es el modo más adecuado para determinar el alcance y el grado relativo de asimilación que se les debería otorgar como sistema de información contable.

La profundidad de los trabajos reseñados y la extensión temporal que abarcan, permiten comprobar, en este tema, la uniformidad conceptual mantenida por el prestigioso académico.

Esta investigación se realiza con el objeto de mostrar el tratamiento

Palabras clave

- comunicación de la responsabilidad social - cuantificación del beneficio social neto - sistema de información contable aconsejado y la expresión que podría formularse con un informe del tipo estudiado, y probar la ineptitud que se le debería reconocer para ofrecerse como estado producido desde la Contabilidad.

\footnotetext{
Abstract

The analysis of the argument used and of the applicable procedures - presented as written testimonies to communicate the social impact of the economic entities, which are the documented opinion of the professor acknowledged as the promoter of these practices in Latin America - is the most suitable way to determine their scope and relative degree of assimilation as an accounting information system.
} 
Keywords - accounting information system - communication of social responsibility - quantification of net social benefit

Palabras-chave

- comunicação de responsabilidade social

- quantificação do benefício social líquido

- sistema de informação contábil
The depth of the works reviewed and the range of time they cover allow us to verify the conceptual uniformity concerning this subject maintained by the prestigious academic.

This research is carried out in order to show the recommended treatment and the expression that could be formulated with a report of this kind, and to prove the ineptitude that should be recognized to be offered as a state produced from Accounting.

\section{Resumo}

A análise da argumentação utilizada e dos procedimentos aplicáveis, apresentados como testemunhos escritos para comunicar os efeitos sociais causados pelas entidades econômicas, que são a opinião documentada do professor que é atribuído como promotor dessas práticas na América Latina é 0 caminho mais adequado para determinar o escopo e 0 grau relativo de assimilação que devem ser concedidos como um sistema de informações contábeis.

A profundidade dos trabalhos revisados e 0 tempo que eles abrangem nos permitem verificar, sobre esse assunto, a uniformidade mantida pelo prestigiado acadêmico.

Esta investigação é realizada com 0 objetivo de mostrar 0 tratamento recomendado e a expressão que poderia ser formulada com um relatório do tipo estudado e provar a inaptidão que deve ser reconhecida para se oferecer como um estado produzido pela Contabilidade. 